\title{
The value of urinary red cell shape in the diagnosis of glomerular and post-glomerular haematuria. A
} meta-analysis

\author{
M. Offringa ${ }^{1,2}$ and J. Benbassat ${ }^{2}$ \\ ${ }^{1}$ Department of Pediatrics, Sophia Children's Hospital and ${ }^{2}$ the Center for Clinical Decision Analysis, \\ University Hospital/Erasmus University, Rotterdam, The Netherlands
}

\begin{abstract}
Summary: The proportion of dysmorphic red cells (DRC) in the urinary sediment and their mean corpuscular volume (MCV) have been claimed to discriminate between glomerular and postglomerular sources of haematuria. To determine the diagnostic value of urinary DRC and MCV, we searched the literature and critically reviewed 21 published studies using a predetermined set of criteria for evaluation.

All studies originated from referral centres. Interobserver variability in identifying urinary DRC was reported in four studies and found to be unacceptably large in one. Although reproducible over different samples of the same individual, urinary MCV was unreliable in cases of low-grade haematuria because of interfering debris. Weighted averages and $95 \%$ confidence limits of the sensitivity and specificity of the DRC proportion for glomerular disease were $0.88(0.86-0.90)$ and $0.95(0.93-0.97)$, respectively; those of a low MCV were $1.00(0.98-1.00)$ for sensitivity and $0.87(0.80-0.91)$ for specificity. Sensitivity and specificity values derived from in-patients were slightly higher than those in referred outpatients. No studies of urinary DRC or MCV in patients with incidentally detected microhaematuria in the primary care setting were found.
\end{abstract}

We conclude that at present the diagnostic value of urinary DRC and MCV is limited. In referral centres, that is, in patients with a high probability of postglomerular haematuria, the test cannot rule out urological lesions, because its specificity for glomerular disease may be as low as 0.80 . In the primary care setting, that is, in unselected patients with incidentally detected low-grade haematuria, the accuracy of the test has not been studied but may be even lower. The use of urinary DRC or MCV as an indicator of the source of haematuria is in need of further experimental development and confirmation.

\section{Introduction}

Asymptomatic microscopic haematuria is a common finding with a reported prevalence of $5 \%^{1}$ to $13 \%^{2}$ in the primary care setting. It may be associated with a wide range of conditions, from transient non-diseases, such as strenous exercise, to bladder cancer. Therefore, physicians frequently face the choice between the risk of missing a significant lesion in a patient with microhaematuria and the inconvenience of invasive examinations. ${ }^{3}$

Determination of urinary red cell (RBC) shape may provide a solution to the problem. ${ }^{4}$ This inexpensive and harmless test has been claimed to be diagnostic for glomerular haematuria and thus identify those who may be exempted from

Correspondence: M. Offringa, M.D., Center for Clinical Decision Analysis, Room EE2171, Erasmus University, PO Box 1738, 3000 DR Rotterdam, The Netherlands. Accepted: 13 January 1992 urological investigations. The presence of dysmorphic red cells (DRC) or of cells with low mean corpuscular volume (MCV) is believed to indicate glomerular bleeding; isomorphic red cells, or cells with a normal MCV are thought to originate from postglomerular sources. However, we know of no published reviews of the accuracy of these tests. How certain is the diagnosis of glomerular haematuria in a patient with DRC in the urine? How confident can one be that the source of bleeding is postglomerular given a finding of isomorphic red cells in the urine? What is the performance of the test in screening for serious urological disorders in various clinical settings?

The purpose of the following meta-analysis is to determine the reliability, sensitivity, specificity and predictive value of urinary DRC and MCV for glomerular disease. Reliability is defined as reproducibility upon repeated applications of the test on the same patient either by the same person (intraobserver reliability) or by two or more independent individuals (interobserver reliability). Test sensi- 
tivity is defined as true positive rate: of all patients with haematuria due to postglomerular disease, the proportion of those with DRC or low MCV. Test specificity is true negative rate: of those with haematuria due to postglomerular disease the proportion of those who excrete isomorphic cells or red cells with normal MCV. Test sensitivity and specificity should not be confused with the test's positive predictive value, which is defined as the proportion of patients with glomerular disease among all of those with DRC or a low MCV.

\section{Methods}

The literature was searched using Medline (1979-1990) and the reference sections of the reviewed articles. We screened all articles identified by the keyword 'haematuria' and found 35 studies of urinary red cell shape published since it was first used to identify the source of haematuria by Birch and Fairley in 1979. Fourteen of these articles ${ }^{4-17}$ were descriptive or technical reports, opinions, non-quantitative studies, or unrelated to the discrimination between glomerular and postglomerular haematuria. Each of the remaining $21^{18-38}$ was reviewed by both authors using the following criteria for evaluation: ${ }^{39}$ (a) description of the test procedure and of the criteria for the interpretation of its results; (b) determination of the reproducibility of the test results (precision) and of its interpretation (observer variation); (c) definition of the setting of the study, of the criteria for patient selection and of the degree and duration of haematuria in the studied patients; (d) 'blind' independent comparison with a gold standard of diagnosis; (e) determinations of the sensitivity and specificity of the test for glomerular disease; and (f) long-term consequences of the use of the test (follow-up of the patients with false-positive and false-negative results).

When possible, the sensitivity and specificity of urinary DRC and MCV for glomerular disease were calculated from the published data. The $95 \%$ confidence limits of the sensitivity and specificity were determined by the exact statistical method. ${ }^{40}$ This method accounts for the relatively small sample sizes and the fact that sensitivity and specificity estimates lie close to 1.0 . Thus, the plausible ranges of these test characteristics' values are indicated to the reader, based on the available data.

Pooled estimates of sensitivity and specificity of both red cell morphology and MCV for glomerular haematuria were calculated using the method of weighted averages. The predictive value of a given test result, e.g. the (post-test) probability of urological disease given a normal MCV, was determined using Bayes' rule ${ }^{39}$ and was based on the disease prevalences and the calculated sensitivities and specificities.

\section{Results}

\section{Test procedures and interpretation}

Two methods have been used to determine urinary red cell shape: the first one consists of determination of the proportion of DRC by phase contrast microscopy (for example, ref. 19), or in stained smears of the urinary sediment; ${ }^{20,23}$ the second method consists of determination of urinary red cell MCV by electronic blood cell counters.

Although both methods have been described in detail, there are considerable differences in the criteria for interpretation of their results. For example, the minimal proportion of DRC considered to indicate glomerular bleeding has varied between 75 and $80 \%,{ }^{25,27,28} 50 \%{ }^{4}$ and $10-14 \%,{ }^{24,29}$ while some authors have not reported the cut-off values used. ${ }^{18,20,23,39}$ In addition to dysmorphic and isomorphic haematuria, a third category of 'mixed' haematuria has been defined, ${ }^{19,25,28}$ and considered to indicate either glomerular ${ }^{27}$ or post-glomerular ${ }^{39}$ bleeding. Still other authors ${ }^{36}$ have used the presence of $2 \%$ or more acanthocytes in the urine as a marker of glomerular haematuria.

There are also considerable differences in the criteria of interpretation of urinary MCV. Most authors have interpreted a unimodal red cell distribution with a MCV of $50 \mathrm{fL}$ or less and $80 \mathrm{fL}$ or more as indicating glomerular and post-glomerular sources of bleeding, respectively; bimodal MCV histograms have been interpreted as 'mixed'. ${ }^{21,22,30}$ Others have used $75 \mathrm{fL}^{37}$ and $72 \mathrm{fL}^{38}$ as cut-off values, while still other authors have claimed that a urinary-blood MCV difference of 0 or less is a better indicator for a glomerular source of haematuria than the absolute MCV value of urinary red cells. ${ }^{31}$

\section{Reliability}

None of the reviewed studies reported estimates of intraobserver variability in interpreting urinary DRC. Interobserver variability was reported in four studies. One of them stated in general terms that the disagreement between observers did not exceed the expected intraobserver variability. ${ }^{24}$ In two studies, independent observers disagreed on the source of haematuria in $10 \%{ }^{20}$ and $25 \%$ of the specimens. The fourth study reported a correlation coefficient of 0.85 between the proportions of DRC reported by two observers. ${ }^{33}$

The reproducibility of urinary red cell MCV was examined in two studies. ${ }^{16,35}$ One of them found almost identical MCV histograms in different urine 
samples of the same individual. ${ }^{35}$ The second ${ }^{16}$ reported that MCV declined with increasing dilutions of the same red cell sample, and that urinary debris interfered with MCV determinations at low red cell concentrations.

\section{Setting, patient selection and degree of haematuria}

All studies were carried out in referred inpatients ${ }^{18-24}$ or outpatients, ${ }^{25-33}$ without defining the criteria of patient referral by the primary care physician, or those of patient selection by the consultant. Two authors ${ }^{28,32}$ reported the inclusion criterion of recurrent haematuria for 3-6 months. The degree of haematuria was either not reported, ${ }^{20-24,29.30,32}$ or defined as more than $3,000-10,000 \mathrm{RBC} / \mathrm{ml},{ }^{19,27,28,39}$ more than $4 \mathrm{RBC} /$ microscopic high power field ${ }^{24}$ or as varying from micro- to gross-haematuria. ${ }^{18,25,26,31}$

\section{Comparison with a gold standard of diagnosis}

Of all cases with haematuria, the proportion of those in whom a definitive diagnosis was reached varied between $14 \%{ }^{30}$ and $94 \%{ }^{24}$ (Table I). Once a cause for haematuria was detected, the investigation was discontinued; it is therefore uncertain, whether the 'mixed haematuria's were produced by two coexisting sources of bleeding or represent a variant originating from a single source. With one exception, ${ }^{41}$ all studies were restricted to those patients in whom the cause of haematuria could be established by kidney biopsies or the presence of red cell casts in cases of glomerular disease, and by cystoscopy and/or contrast urography in cases of postglomerular lesions. In all studies the urinary red cell shape was interpreted by observers who were blinded to the diagnosis.

\section{Sensitivity and specificity of DRC and MCV for glomerular disease}

Of the 21 studies reviewed, five $e^{23,24,33-35}$ reported the agreement between the test results and the gold standard only in global terms, thus precluding the calculation of sensitivity and specificity of urinary red cell shape for glomerular disease. Thal ${ }^{23}$ and Pillsworth et al.$^{24}$ did not provide sufficient data for the calculation of the sensitivity and specificity. Escobedo et al. ${ }^{34}$ reported an agreement rate of

Table I Reviewed articles on the discrimination between glomerular and postglomerular microhaematuria by urinary red cell shape. Numbers of patients with definitive diagnosis and postglomerular disease

\begin{tabular}{|c|c|c|c|c|c|}
\hline Authors & Reference & $\begin{array}{l}\text { Proportion of } \\
\text { patients with } \\
\text { definitive diagnosis }\end{array}$ & $(\%)$ & $\begin{array}{l}\text { Proportion of patients } \\
\text { with postglomerular } \\
\text { disease }\end{array}$ & $(\%)$ \\
\hline \multicolumn{6}{|l|}{ In-patients } \\
\hline $\begin{array}{l}\text { Rizzoni et al. } \\
\text { Birch et al. } \\
\text { Chang } \\
\text { Docci et al. } \\
\text { Tsukahara et al. } \\
\text { Thal et al. } \\
\text { Pillsworth et al. }\end{array}$ & $\begin{array}{l}18 \\
19 \\
20 \\
21 \\
22 \\
23 \\
24\end{array}$ & $\begin{array}{l}106 / 179 \\
117 / 141 \\
20 / . . \\
54 / 60 \\
80 / . . \\
. . / . \\
65 / 69\end{array}$ & $\begin{array}{l}(59) \\
(83) \\
(90) \\
(94)\end{array}$ & $\begin{array}{l}41 / 106 \\
30 / 117 \\
10 / 20 \\
39 / 54 \\
24 / 80 \\
. . / . . \\
47 / 65\end{array}$ & $\begin{array}{l}(39) \\
(26) \\
(50) \\
(72) \\
(30) \\
(72)\end{array}$ \\
\hline \multicolumn{6}{|l|}{ Outpatients } \\
\hline $\begin{array}{l}\text { Fassett et al. } \\
\text { Fairley and Birch } \\
\text { Raman et al. } \\
\text { De Santo et al. } \\
\text { Stapleton } \\
\text { Shichiri et al. } \\
\text { Banks et al. } \\
\text { Funfstuck et al. } \\
\text { Pollock et al. }\end{array}$ & $\begin{array}{l}25 \\
26 \\
27 \\
28 \\
29 \\
30 \\
31 \\
32 \\
33\end{array}$ & $\begin{array}{l}253 / 303 \\
88 / . . \\
89 / 109 \\
168 / . . \\
45 / . . \\
146 / 1012 \\
42 / . . \\
210 / . . \\
41 / 64\end{array}$ & $\begin{array}{l}(14) \\
(64)\end{array}$ & $\begin{array}{l}113 / 253 \\
30 / 88 \\
44 / 89 \\
82 / 168 \\
20 / 45 \\
79 / 146 \\
21 / 42 \\
75 / 210 \\
25 / 41\end{array}$ & $\begin{array}{l}(45) \\
(34) \\
(49) \\
(49) \\
(44) \\
(54) \\
(50) \\
(36) \\
(61)\end{array}$ \\
\hline \multicolumn{6}{|l|}{ Setting not reported } \\
\hline $\begin{array}{l}\text { Escobado et al. } \\
\text { Caestecker et al. } \\
\text { Kohler et al. } \\
\text { Fairley et al. } \\
\text { Goldwasser } \text { et al. }\end{array}$ & $\begin{array}{l}34 \\
35 \\
36 \\
37 \\
38\end{array}$ & $\begin{array}{l}40 / . . \\
120 / . . \\
205 / . . \\
41 / . . \\
30 / 34\end{array}$ & $(88)$ & $\begin{array}{l}. . / 40 \\
79 / 120 \\
100 / 205 \\
14 / 41 \\
14 / 30\end{array}$ & $\begin{array}{l}(66) \\
(49) \\
(34) \\
(47)\end{array}$ \\
\hline
\end{tabular}


$57 \%$ for DRC and $80 \%$ for MCV. De Caestacker et al. ${ }^{35}$ reported that the agreement between urinary red cell MCV and the gold standard was $100 \%$ in cases with gross haematuria. However, in more than half of their cases of microhaematuria, MCV could not be determined because of interfering urinary debris. DRC classified correctly $52 \%$ of the cases, incorrectly $10 \%$ and was 'not diagnostic' in $38 \%$. The proportion of incorrectly diagnosed cases increased with decreasing degrees of microhaematuria. Pollock et al. ${ }^{33}$ has similarly reported a very poor agreement between the test results and the gold standard, with a marked overlap in the proportion of DRC in patients with glomerular and postglomerular lesions.

The sensitivity and specificity of the proportion of DRC and MCV for glomerular disease were derived from the results of the 16 remaining studies. It should be noted that the averages of the test characteristics of the urinary red cells' MCV were based on a total of four studies only. ${ }^{21,22,30,31}$ When applicable, 'mixed' haematuria was considered as isomorphic (i.e. as indicating postglomerular bleeding). The sensitivity of DRC for glomerular disease ranged from $0.21^{27}$ to $1.0^{20}$ (Table II), while that of MCV was 1.0 when a cut-off value of $50 \mathrm{fL}$ was used (Table III). Two other studies have reported a sensitivity of 1.00 and 0.89 using cut-off values of 75 and $72 \mathrm{fL}$, respectively. ${ }^{37,38}$ The specificity of DRC and MCV ranged from $0.75^{27}$ to $1.0^{19,20,26}$ and from $0.80^{30}$ to $0.97,{ }^{21}$ respectively. There was a wider variation of the data derived from studies of urinary DRC than those derived from urinary MCV. The weighted averages and $95 \%$ confidence intervals derived from determinations of urinary DRC in outpatients were 0.84 $(0.80-0.86)$ for sensitivity and $0.92(0.89-0.94)$ for specificity; those derived from MCV studies of outpatients were $1.0(0.97-1.0)$ for sensitivity and $0.80(0.71-0.87)$ for specificity (Tables II and III). As expected the sensitivity of the test increased with a corresponding decline in its specificity when the finding of 'mixed' haematuria was assumed to indicate glomerular bleeding.

\section{Calculation of the predictive value of urinary red cell shape}

The predictive value of any test depends on its sensitivity and specificity, but also on the prevalence of the disease in question in the population from which the patient is drawn, the so-called 'pretest probability' or prior probability of disease'.$^{39}$ The pooled sensitivity of a low urinary red cell MCV for glomerular disease was 1.0, while its specificity was 0.87 (Table III). The prevalence of postglomerular (urological) disorders in the reviewed series varied from 26 to $72 \%$ (Table I). After applying Bayes' rule, ${ }^{39}$ a finding of low MCV haematuria would reduce the probability of urological disease to 4 and $25 \%$, respectively. In other words, the source of haematuria may turn out to be urological in as many as $4-25 \%$ of referred patients with low MCV haematuria.

\section{Urinary red cell shape in normal subjects}

Asymptomatic and healthy individuals have been shown to excrete up to $3,000^{8}$ and $8,000^{19}$ red blood cells per ml urine. The red cells excreted by healthy controls were reported to be of dysmorphic appearance. ${ }^{8,19}$ However, in another study of normal controls Fasset et al. ${ }^{8}$ reported that 'many (normal) subjects had distorted cells similar to those seen in patients with glomerulonephritis, but many also had non-glomerular cells'. Physical exercise in healthy adults is known to be associated with urinary abnormalities, including haematuria. ${ }^{8,9}$ Urinary red cell morphology after exercise has been reported to be of dysmorphic ${ }^{8,9}$ and isomorphic ${ }^{17}$ types.

\section{Discussion}

The presented survey of the diagnostic value of urinary red cell shape identified several limitations, which at present preclude its application as a definitive discriminating test between glomerular and postglomerular haematuria. First, all studies were carried out on patients who passed the triple filter of referral by the primary care physician, selection by the consultant and eventual establishment of a certain diagnosis. These were highly selected patients who probably had recurrent rather than transient haematuria, or with more severe bleeding rather than the whole spectrum haematuria. In general, diagnostic tests perform better in patients with more severe disease. ${ }^{42}$ Therefore, the calculated averages of the test properties are appropriate for referral centres, but may not be applicable in the primary care setting.

Second, the uncertain inter- and intraobserver agreement in identifying DRC and the variability in the proportions of DRC used as a cut-off between glomerular and non-glomerular bleeding indicate that the reliability (reproducibility) of the test is, at best, conditional on expertise. Urinary red cell MCV determinations are less affected by subjective interpretations and their sensitivity and specificity are higher and more consistent than those of urinary DRC. However, MCV determinations may not be reliable in patients with low-grade haematuria. ${ }^{16,35}$

Even ignoring the poor reliability of urinary red cell shape determinations, the presented survey indicates that a finding of low MCV haematuria in a referred patient would reduce the probability, but 
Table II Sensitivity and specificity (95\% confidence interval) of dysmorphic urinary red cells for glomerular microhaematuria

\begin{tabular}{|c|c|c|c|c|}
\hline Reference & Sensitivity & $(95 \% C I)$ & Specificity & $(95 \% C I)$ \\
\hline \multicolumn{5}{|l|}{ In-patients } \\
\hline $\begin{array}{l}\text { Rizzoni et al. }{ }^{18} \\
\text { Birch et al } .^{19} \\
\text { Chang }\end{array}$ & $\begin{array}{l}0.97 \\
0.90 \\
1.00\end{array}$ & $\begin{array}{l}(0.89-0.99) \\
(0.81-0.95) \\
(0.74-1.00)\end{array}$ & $\begin{array}{l}0.95 \\
1.00 \\
1.00\end{array}$ & $\begin{array}{l}(0.84-0.99) \\
(0.90-1.00) \\
(0.74-1.00)\end{array}$ \\
\hline $\begin{array}{l}\text { Weighted averages } \\
\text { (three studies) }\end{array}$ & 0.93 & $(0.88-0.97)$ & 0.98 & $(0.91-0.99)$ \\
\hline \multicolumn{5}{|l|}{ Outpatients } \\
\hline $\begin{array}{l}\text { Fassett et al. } .^{25} \\
\text { Fairley and Birch } \\
\text { Raman et al. } \\
\text { Raman et al. } \\
\text { De Santo }{ }^{27 *} \text { al } \\
\text { Stapleton }{ }^{29} \\
\text { Funfstuck et al. } .^{32}\end{array}$ & $\begin{array}{l}0.82 \\
0.95 \\
0.62 \\
0.21 \\
0.95 \\
0.92 \\
0.95\end{array}$ & $\begin{array}{l}(0.75-0.88) \\
(0.86-0.99) \\
(0.46-0.76) \\
(0.09-0.39) \\
(0.88-0.99) \\
(0.74-0.99) \\
(0.90-0.98)\end{array}$ & $\begin{array}{l}0.96 \\
1.00 \\
0.75 \\
0.83 \\
0.96 \\
0.93 \\
0.92\end{array}$ & $\begin{array}{l}(0.90-0.98) \\
(0.90-1.00) \\
(0.60-0.87) \\
(0.66-0.93) \\
(0.90-0.99) \\
(0.68-0.99) \\
(0.83-0.97)\end{array}$ \\
\hline $\begin{array}{l}\text { Weighted averages } \\
\text { (six studies) }\end{array}$ & 0.84 & $(0.80-0.86)$ & 0.92 & $(0.89-0.94)$ \\
\hline \multicolumn{5}{|l|}{ Setting not reported } \\
\hline $\begin{array}{l}\text { Kohler et al }{ }^{36} \dagger \\
\text { Fairley et al. }{ }^{37} \\
\text { Goldwasser et al. }{ }^{38}\end{array}$ & $\begin{array}{l}0.78 \\
0.96 \\
0.88\end{array}$ & $\begin{array}{l}(0.68-0.86) \\
(0.81-0.99) \\
(0.64-0.98)\end{array}$ & $\begin{array}{l}1.00 \\
1.00 \\
1.00\end{array}$ & $\begin{array}{l}(0.97-1.00) \\
(0.81-1.00) \\
(0.76-1.00)\end{array}$ \\
\hline $\begin{array}{l}\text { Weighted averages } \\
\text { (three studies) }\end{array}$ & 0.83 & $(0.75-0.88)$ & 1.00 & $(0.97-1.00)$ \\
\hline $\begin{array}{l}\text { Weighted averages } \\
\text { (all } 12 \text { studies) }\end{array}$ & 0.88 & $(0.86-0.90)$ & 0.95 & $(0.93-0.97)$ \\
\hline
\end{tabular}

${ }^{*}$ Results of two independent observers. Only the results of 27a were considered in calculating the weighted averages; †glomerular haematuria diagnosed as urinary acanthocytosis exceeding $2 \% ; \mathrm{CI}=$ confidence intervals.

Table III Sensitivity and specificity ( $95 \%$ confidence interval) of urinary red cell mean corpuscular volume $<50 \mathrm{fL}$ for glomerular microhaematuria

\begin{tabular}{lcccc}
\hline Reference & Sensitivity & $(95 \%$ CI $)$ & Specificity & $(95 \%$ CI $)$ \\
\hline $\begin{array}{l}\text { In-patients } \\
\quad \begin{array}{l}\text { Docci } \text { et al. }{ }^{21} \\
\text { Tsukahara } \text { et al. }\end{array}\end{array}$ & 1.00 & $(0.82-1.00)$ & 0.97 & $(0.86-0.99)$ \\
$\begin{array}{l}\text { Weighted averages } \\
\text { (two studies) }\end{array}$ & 1.00 & $(0.95-1.00)$ & 0.96 & $(0.79-0.99)$ \\
$\begin{array}{l}\text { Outpatients } \\
\quad \begin{array}{l}\text { Shichiri } \text { et al al } \\
\text { Banks } \text { et al. }\end{array}\end{array}$ & 1.00 & $(0.96-1.00)$ & 0.97 & $(0.89-0.99)$ \\
$\begin{array}{l}\text { Weighted averages } \\
\text { (two studies) }\end{array}$ & 1.00 & $(0.96-1.00)$ & 0.80 & $(0.69-0.88)$ \\
$\begin{array}{l}\text { Weighted averages } \\
\text { (all four studies) }\end{array}$ & 1.00 & $(0.87-1.00)$ & 0.81 & $(0.58-0.95)$ \\
\hline
\end{tabular}

$\mathrm{CI}=$ confidence intervals. 
not exclude the possibility of urological disease. These limitations of the test were evident also in the only study of the long-term consequences of its use. Schramek and his associates ${ }^{41}$ studied 316 referred patients with symptomless microhaematuria, 123 of whom excreted isomorphic red cells. Of these 123 patients, postglomerular sources of bleeding, including 10 urothelial malignancies, were identified in 104. The remaining 193 patients with dysmorphic haematuria had no further investigations, but were carefully followed for at least 2 years. Bladder cancer and nephrolithiasis were diagnosed in two patients 2 and 4 years later, respectively. The authors concluded that microscopic analysis of urinary erythrocyte morphology is '.. an effective method for identifying patients with symptomless microhaematuria needing specific diagnostic investigation'. Yet, two urological lesions were diagnosed in patients initially thought to have had glomerular haematuria. These lesions may have been a late development; alternatively, they may have been missed by the examination of urinary morphology.

Despite its limited value in referred patients, urinary red cell MCV could be useful in the primary care setting, where the prevalence of urological disorders is lower than in referral centres. Given a low pretest probability, the test could identify persons with symptomless microhaematuria who are at a still lower risk of urological disorders and therefore may be exempted from immediate investigations. However, urinary MCV has never been studied in the primary care setting, and its diagnostic value in persons with incidentally detected low-grade haematuria is uncertain.

We conclude that at present the use of urinary red cell shape as an indicator of the source of haematuria is in need of further experimental development and evaluation. In order to improve their reproducibility the criteria for identification of DRC must be rigidly standardized and the cut-off values separating between glomerular and postglomerular bleeding should be redefined in order to maximize specificity. The reliability of MCV determinations in cases of microhaematuria will have to be reassessed. Only then will it be possible to evaluate whether the test's sensitivity, specificity and predictive value warrant its use in the investigation of haematuria.

\section{Acknowledgement}

This work was supported by a grant from the Netherlands Health Research Promotion Programme (SGO) to the Rotterdam Center for Clinical Decision Analysis. The authors are indebted to Dr P.M.M. Bossuyt for his advice and to Professor Dr J. Lubsen for his constructive comments.

\section{References}

1. Froom, P., Ribak, J. \& Benbassat, J. Significance of microhaematuria in young adults. $\mathrm{Br}$ Med $J$ 1984, 288: 20-22.

2. Mohr, D.N., Offord, K.P., Owen, R.A. \& Melton, J. Asymptomatic microhaematuria and urologic disease. A population study. JAMA 1986, 256: 224-229.

3. Livingstone, V. Asymptomatic microscopic haematuria revisited. Can Fam Physic 1985, 31: 2179-2185.

4. Birch, D.F. \& Fairley, K.F. Haematuria: glomerular or non-glomerular? Lancet 1979, ii: 845.

5. Pellet, H., Thonnerieux, M., Depardon, J. et al. Microscopic haematuria: renal or extrarenal? Phase contrast microscopy of urinary sediment. Kidney Int 1982, 21: 124 (Abstract).

6. Birch, D.F. \& Fairley, K.F. Red cells in the urine. Lancet 1980, i: 424.

7. Schifferli, J., Rees, A.J. \& Pearse, E. Haematuria: glomerular or non-glomerular? Lancet 1979, ii: 1014.

8. Fassett, R.G., Owen, J.E., Fairley, J., Birch, D.F. \& Fairley, K.F. Urinary red-cell morphology during exercise. $\mathrm{Br} \mathrm{Med} \mathrm{J}$ (Clin Res) 1982, 285: 1455-1457.

9. Reid, R.I., Hosking, D.H. \& Ramsey, E.W. Haematuria following a marathon run: source and significance. $\mathrm{Br} J$ Urol 1987, 59: 133-136.

10. Fassett, R.G., Horgan, B., Gove, D. \& Mathew, T.H. Scanning electron microscopy of glomerular and non glomerular red blood cells. Clin Nephrol 1983, 20: 11-16.

11. Punt, J.M. Urine sediment in painless haematuria: an underevaluated diagnostic sign (letter). Ned Tijdschr Geneeskd 1989, 13: 1995-1996.

12. Adomssent, G. \& Stolpe, H.J. The significance of erythrocyte morphology for the differential diagnosis of haematuria. Kinderarztl Prax 1989, 57: 171-176.
13. Muller, V., Siegel, O., Siegel, S. et al. Differentiation of haematuria by phase contrast microscopy studies of urine erythrocytes. Z Urol Nephrol 1989, 82: 277-283.

14. Gibbs, D.D. \& Lynn, K.L. Red cell volume distribution curves in the diagnosis of glomerular and non-glomerular haematuria. Nephron 1990, 54: 366-367.

15. Turitzin, S.N., Rottelar, C., Mackow, R.C., Pahira, J.J., Rakowski, T.A. \& Winchester, J.F. Effect of extracorporeal shock wave lithotripsy and urine osmolality on urine red cell morphology. Kidney Int 1990, 37: 284 (Abstract).

16. Gibbs, D.D. \& Lynn, K.L. Red cell distribution curves in the diagnosis of glomerular and non-glomerular haematuria. Clin Nephrol 1990, 33: 143-147.

17. Siegel, A.J., Hennekens, C.H., Solomon, H.S. \& van Boeckel, B. Exercise related haematuria. Findings in a group of marathon runners. JAMA 1979, 241: 391-392.

18. Rizzoni, G., Braggion, F. \& Zacchello, G. Evaluation of glomerular and nonglomerular haematuria by phase-contrast microscopy. J Pediatr 1983,103: P 370-374.

19. Birch, D.F., Fairley, K.F., Whitworth, J.A. et al. Urinary erythrocyte morphology in the diagnosis of glomerular haematuria. Clin Nephrol 1983, 20: 78-84.

20. Chang, B.S. Red cell morphology as a diagnostic aid in haematuria. JAMA 1984, 252, 1747-1749.

21. Docci, D., Delvecchio, C., Turci, A., Turci, F., Baldrati, L. \& Martinelli, A. Detection of glomerular bleeding by urinary-red-cell-size distribution. Nephron 1988, 50: $380-382$. 
22. Tsukahara, H., Yoshimoto, M., Morikawa, K., Okada, T., Kuroda, M. \& Sudo, M. Urinary erythrocyte volume analysis: a simple method for localizing the site of haematuria in pediatric patients. $J$ Pediatr 1989, 115: 433-436.

23. Thal, S.M., Debellis, C.C., Iverson, S.A. \& Scumann, G.B. Comparison of dysmorphic erythrocytes with other urinary sediment parameters of renal bleeding. Am J Clin Pathol 1986, 86: 784-787.

24. Pillsworth, T.J. Jr, Haver, V.M., Abrass, C.K. \& Delaney, C.J. Differentiation of renal from non-renal haematuria by microscopic examination of erythrocytes in urine. Clin Chem 1987, 33: $1791-1795$.

25. Fassett, R.G., Horgan, B.A. \& Mathew, T.H. Detection of glomerular bleeding by phase-contrast microscopy. Lancet 1982, i: $1432-1434$.

26. Fairley, K.F. \& Birch, D.F. Haematuria: a simple method of identifying glomerular bleeding. Kidney Int 1982, 21: 105.

27. Raman, G.V., Pead, L., Lee, H.A. \& Maskell, R. A blind controlled trial of phase contrast microscopy by two observers for evaluating the source of haematuria. Nephron 1986, 44: 306-308.

28. De Santo, N.G., Nuzzi, F., Capodicasa, G. et al. Phase contrast microscopy of the urine sediment for the diagnosis of glomerular and nonglomerular bleeding - data in children and adults with normal creatinine clearance. Nephron 1987, 45: 35-39.

29. Stapleton, F.B. Morphology of urinary red blood cells: a simple guide in localizing the site of haematuria. Pediatr Clin North Am 1987, 34: 561-569.

30. Shichiri, M., Hosoda, K., Nishio, Y. et al. Red-cell-volume distribution curves in diagnosis of glomerular and non-glomerular haematuria. Lancet 1988, i: 908-911.

31. Banks, R.A., Reynolds, S. \& Hanbury, D. Identification of the source of haematuria by automated measurement of red cell volume. Br J Urol 1989, 64: 45-48.

32. Funfstuck, R., Schuster, F.X., Stein, G., Beintker, M., Schramek, P. \& Jansa, U. The significance of erythrocyte morphology in glomerular and non-glomerular haematuria. Z Urol Nephrol 1989, 82: 85-91.
33. Pollock, C., Pei-Ling, L., Gyorgy, A.Z. et al. Dysmorphism of urinary red blood cells. Value in diagnosis. Kidney Int 1989, 36: 1045-1049.

34. Escobedo, J.M., Belda, J., Sosa, M.A. et al. Urine erythrocyte morphology and volume distribution curves in the study of haematuria of glomerular and non-glomerular origin. Kidney Int 1990, 37: 1518 (Abstract).

35. Caestecker, M.P., Hall, C.L., Basterfield, P.T. \& Smith, J.G. Localization of haematuria by red cell analysers and phase-contrast microscopy. Nephron 1989, 52: 170-173.

36. Kohler, H., Wandel, E. \& Dumann, H. Acanthocyturia - a characteristic marker in the diagnosis of glomerular haematuria. Kidney Int 1990, 37: 258 (Abstract).

37. Fairley, K., Bennet, W.M., Fairley, S. \& Birch, D. Comparison of red cell volume distribution by Coulter counter to phase contrast microscopy in the differentiation of glomerular from non-glomerular haematuria. Kidney In 1990, 37: 1172 (Abstract).

38. Goldwasser, P., Antigani, A., Mittman, N. et al. Urinary red cell size: diagnostic value and determinants. Am J Nephro 1990, 10: $148-156$.

39. Sackett, D.L., Hayes, R.B. \& Tugwell, P. Clinical Epidemiology. A Basic Science for Clinical Medicine. Little, Brown and Company, Boston, 1985.

40. Armitage, P. \& Berry, G. Statistical Methods in Medical Research, 2nd ed. Blackwell, Oxford, 1987, pp. 117-120.

41. Schramek, P., Schuster, F.X., Georgopoulos, M., Porpaczy, P. \& Maier, M. Value of urinary erythrocyte morphology in assessment of symptomless microhaematuria. Lancet 1989, ii: $1316-1319$.

42. Sox, H.C., Blatt, M.A., Higgins, M.C. \& Marton, K.I. Medical Decision Making. Butterworths, Boston, 1988. 